Contemporary Philosophy: A New Survey

Guttorm Fløistad Editor
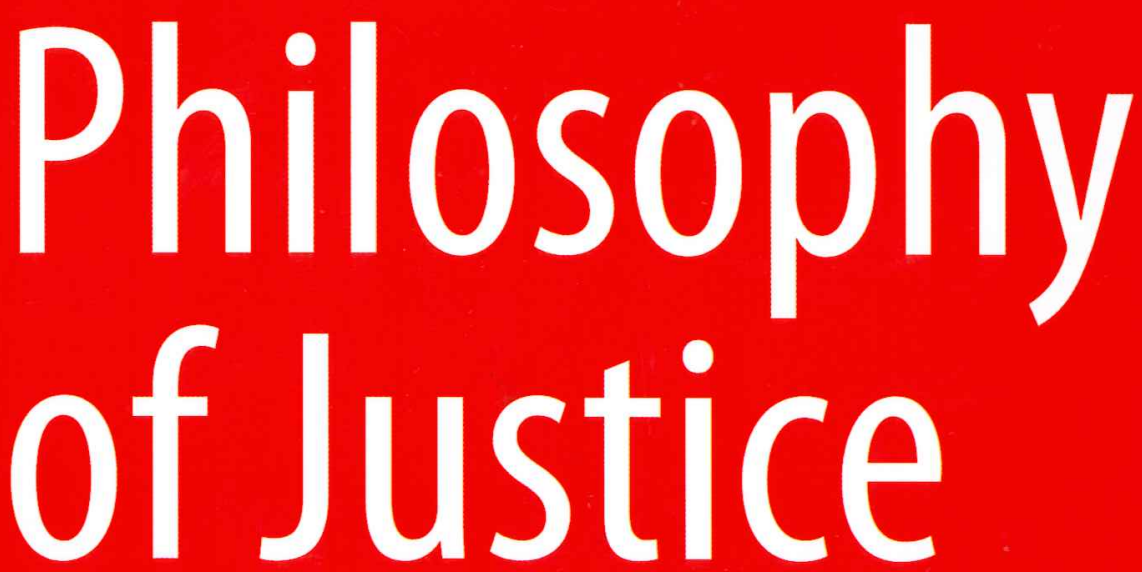

Springer 


\section{International Institute of Philosophy}

\section{Contemporary Philosophy \\ A New Survey}

edited by

GUTTORM FLØISTAD

University of Oslo

Volume 12

Philosophy of Justice 
Editor

Guttorm Fløistad

Institute for the History of Ideas

University of Oslo

Oslo, Norway

Philosophy of Justice/edited by Guttorm Fløistad

p.cm. - (Contemporary Philosophy, A New Survey; v. 12)

English and French

Includes bibliographical references and index.

Published under the auspices of the International Council of Philosophy and Humanistic Studies and of the International Federation of Philosophical Societies, with the support of UNESCO.

Publié sous les auspices du Conseil International de la Philosophie et des Sciences Humaines et de la Fédération Internationale des Sociétés de Philosophie, avec le concours de l'UNesco.

ISBN 978-94-017-9174-8

DOI 10.1007/978-94-017-9175-5

Springer Dordrecht Heidelberg New York London

Library of Congress Control Number: 2014946578

(C) Springer Science+Business Media Dordrecht 2015

This work is subject to copyright. All rights are reserved by the Publisher, whether the whole or part of the material is concerned, specifically the rights of translation, reprinting, reuse of illustrations, recitation, broadcasting, reproduction on microfilms or in any other physical way, and transmission or information storage and retrieval, electronic adaptation, computer software, or by similar or dissimilar methodology now known or hereafter developed. Exempted from this legal reservation are brief excerpts in connection with reviews or scholarly analysis or material supplied specifically for the purpose of being entered and executed on a computer system, for exclusive use by the purchaser of the work. Duplication of this publication or parts thereof is permitted only under the provisions of the Copyright Law of the Publisher's location, in its current version, and permission for use must always be obtained from Springer. Permissions for use may be obtained through RightsLink at the Copyright Clearance Center. Violations are liable to prosecution under the respective Copyright Law.

The use of general descriptive names, registered names, trademarks, service marks, etc. in this publication does not imply, even in the absence of a specific statement, that such names are exempt from the relevant protective laws and regulations and therefore free for general use.

While the advice and information in this book are believed to be true and accurate at the date of publication, neither the authors nor the editors nor the publisher can accept any legal responsibility for any errors or omissions that may be made. The publisher makes no warranty, express or implied, with respect to the material contained herein.

Printed on acid-free paper

Springer is part of Springer Science+Business Media (www.springer.com) 


\title{
Justice and Moderation in the State: Aristotle and Beyond
}

\author{
Eleni Leontsini
}

\section{The Centrality of Political Justice}

In this chapter I aim to analyze Aristotle's account of political justice (to politikon dikaion) in both the Nicomachean Ethics and the Politics, ${ }^{1}$ since it is these accounts that are most relevant to his advocacy of moderation and mixed constitution, and I aim to show how justice (dikaiosunē) and equality (isotēs) are crucial for the promotion of the common interest (to koine symferon) of the state (polis). In addition, I explore the connection made between justice (dikaiosume ; aplōs or politikon dikaion), equality (isotēs), democracy (demokratia), liberty (eleutheria), and friendship (philia), and attempt to further excavate Aristotle's conception of political justice (to politikon dikaion) and moderation in the polis. We will see how this bears on questions in contemporary political philosophy concerning the role of justice as the most fundamental virtue for society, and as an institution that serves to fix the limits of human conduct and to lay down the principles specifying the just distribution of benefits and burdens in a democratic society of equals.

It should be noted that Aristotle's account of justice as presented in both the Nicomachean Ethics and the Politics is complex and that there are many concepts of justice discussed by Aristotle. Indeed, Aristotle is aware of this complexity in justice, as he makes sure to stress in NE II.7.1108b17-19: "With regard to justice, since it has not one simple meaning, we shall, after describing the other states, distinguish its two kinds and say how each of them is a mean". For Aristotle, there are universal

\footnotetext{
'Abbreviations: NE (Nicomachean Ethics), EE (Eudemian Ethics), Pol (Politics), Rhet (Rhetoric). Translations from Aristotle's Nicomachean Ethics and Politics are from Ross, D. (1980) Aristotle Nicomachean Ethics. Oxford: Oxford University Press, and Stalley, R. F. (1995) Aristotle. The Politics. Oxford: Oxford University Press, respectively, and the translations of Aristotle's other works are from Barnes, J. (1984) The Complete Works of Aristotle, 2 vols. Princeton: Princeton University Press, with some alterations of my own.
}

E. Leontsini $(\bowtie)$

Department of Philosophy, University of Ioannina, Epiros, Greece

e-mail: eleon@uoi.gr 
and particular concepts of justice as well as natural and conventional ones. Especially in the Nicomachean Ethics, there are many concepts of justice discussed, and the main distinction made in NE V.1-2 is between 'universal' and 'particular' justice.

According to Aristotle, 'universal' or 'general' justice ('the just as the lawful') refers to the whole of virtue:

This form of justice, then, is complete virtue, although not without qualification, but in relation to our neighbour. And therefore justice is often thought to be the greatest of virtues, and 'neither evening nor morning star' is so wonderful; and proverbially 'in justice is every virtue comprehended'. And it is complete virtue in its fullest sense because it is the actual exercise of complete virtue. It is complete because he who possesses it can exercise his virtue not only in himself but towards his neighbour also; for many people can exercise virtue in their own affairs, but not in their relations to their neighbour ( $N E$ V.1129b25-35).

This universal or general concept of justice includes all the habits and dispositions of a good citizen and aims at the common advantage (to koinē symferon): "The laws in their enactments on all subjects aim at the common advantage either of all or of the best or of those who hold power, or something of the sort; so that in one sense we call those acts just that tend to produce and preserve happiness and its components for the political society" ( $N E$ V.1129b15-19). As Young succinctly points out, "The identity of universal justice, lawfulness, and virtue as a whole thus brings together two major themes of Aristotle's moral and political philosophy: the moral idea that acting virtuously promotes happiness and the political idea that the political community exists to promote the happiness of its citizens".'2

'Particular' justice ('the just as the fair and equal') is a character virtue, like the other virtues (for example, courage, temperance, liberality, honesty, loyalty, etc.), and is part of 'universal' justice. Particular justice is divided into two kinds: distributive justice (dianemétikon dikaion) and corrective (or rectificatory or commutative) justice (diorthötikon dikaion). Distributive justice operates in a society and allocates benefits and burdens fairly, while rectificatory justice operates between two parties and either maintains or restores a balance (NE V.2). ${ }^{3}$

My analysis will mainly focus on the discussion of the Aristotelian conception of political justice which is introduced in $N E$ V.6. Having demonstrated that the reciprocal is related to the just, Aristotle points out that "we must not forget that what we are looking for is not only what is just without qualification (to aplōs dikaion) but also political justice (to politikon dikaion)" (NE V.6. 1134a25-26):

This is found among people who share their life with a view to self-sufficiency, people who are free and either proportionately or arithmetically equal, so that between those who do not fulfil this condition there is no political justice in a special sense or by analogy. For justice exists only between people whose mutual relations are governed by law; and law exists for people between whom there is injustice; for legal justice is the discrimination of the just and the unjust. And between people between whom injustice is done there is also unjust action (although there is not injustice between all between whom there is unjust action), and this

${ }^{2}$ Young, C. M. (2007) "Aristotle's Justice," in Kraut, R. (ed.) The Blackwell Guide to Aristotle's Nicomachean Ethics. Oxford: Blackwell, p. 181.

${ }^{3}$ For a clear exposition of the main concepts of justice presented in $N E \mathrm{~V}$, see Young, C. M. "Aristotle's Justice," op. cit., pp. 179-180. 
is assigning too much to oneself of things good in themselves and too little of things evil in themselves. This is why we do not allow a person to rule, but rational principle, because a person behaves thus in his own interests and becomes a tyrant. The magistrate on the other hand is the guardian of justice, and, if of justice, then of equality also (NE V.6. 1134a26-1134b2).

Justice (dikaiosune or politikon dikaion) is central to Aristotle's political theory; it is the chief virtue of the polis that promotes the common advantage (to koine symferon). As Aristotle points out in Politics III, repeating in a way the argument of the first section of the first chapter of Politics $\mathrm{I}^{4}$ :

In all branches of knowledge and in every kind of craft the end in view is some good. In the most sovereign of these, the capacity for [leadership in] political matters, the end in view is the greatest good and the good which is most to be pursued. The good in the sphere of politics is justice (dikaion), and justice consists in what tends to promote the common interest (to koine symferon) (Pol III.1282b12-14).

The centrality of justice in Aristotle's political thought is obvious from the very beginning of Politics I.2. There, Aristotle defends something we can call 'political naturalism'; the idea is that human beings have the natural impulse to live together and to form political associations. ${ }^{5}$ He argues that human beings-being political animals by nature - are uniquely endowed by nature with the ability to form the concept of justice and with the capacity for political co-operation ( $P o l$ I.1253a7-18): "The city belongs to the class of things that exist by nature, and man is by nature a political animal" (Pol 1253a1-3). In addition, Aristotle argues in Pol I.1253a31-39 that, although the impulse towards these kinds of associations exists by nature in all people, "the person who first constructed such an association was nonetheless the greatest of all benefactors". This also contains the claim that human beings need law and justice in order to form a political association. ${ }^{6}$ Aristotle illustrates this point further by pointing out that:

\begin{abstract}
Man, when perfected, is the best of animals; but if he be isolated from law and justice he is the worst of all. Injustice is all the graver when it is armed injustice; and man is furnished from birth with weapons which are intended to serve the purposes of wisdom and goodness, but which may be used in preference for opposite ends. That is why, if he be without goodness [of mind and character], he is a most unholy and savage being, and worse than all others in the indulgence of lust and gluttony. The virtue of justice belongs to the city; for justice is an ordering of the political association, and the virtue of justice consists in the determination of what is just. (Pol I.1253a29-39)
\end{abstract}

As we have seen, according to Aristotle, justice is important since its purpose is the common advantage of the polis (to koine symferon). It is interesting that he also relates political friendship with the promotion of the common advantage of the

\footnotetext{
${ }^{4}$ Barker, E. (ed.) (1958) The Politics of Aristotle. Oxford: Oxford University Press, p. 129.

${ }^{5}$ For an extensive discussion of Aristotle's political naturalism and the relevant bibliography, see Leontsini, E. (2007) The Appropriation of Aristotle in the Liberal-Communitarian Debate, with a foreword by R. F. Stalley. Athens: Saripolos Library, pp. 49-92.

${ }^{6}$ See Miller, Fr. D. (1995) Nature, Justice, and Rights in Aristotle's Politics. Oxford: Clarendon Press, p. 67.
} 
polis, as we shall see in Sect. 4 of this chapter. In addition, it should be pointed out that the common advantage of the polis (to koine symferon) is also associated with both democracy and polity as well as with his constitutional theory in general ( $P o l$ III.6.1279a17ff.; III.9.1280a10; III.9.1280a22; V.1.1301a36; V.1.1301b36). The best constitution (politeia) is the one that aims at the common interest or advantage ( $P o l$ III.4.1277b7-9 \& III.6.1278b6-25). As Aristotle points out, justice is restricted to cities with good rulers, irrespectively of the type of constitution followed:

Those constitutions which consider the common interest are right constitutions, judged by the standard of absolute justice. Those constitutions which consider only the personal interest of the rulers are all wrong constitutions, or perversions of the right forms. Such perverted forms are despotic; whereas the city is an association of free people (Pol III.7. 1279a $17-21)$.

\section{Justice and Equality in the Politics}

In addition, there is an interesting connection, made by Aristotle in various passages, between justice and equality and their relevance to the promotion of moderation in the city. ${ }^{7}$ Aristotle's theory of constitutions confirms the centrality of justice for Aristotelian political theory. This is clearly stated in Politics III.1282b14-18: "The good in the sphere of politics is justice, and justice consists in what tends to promote the common interest. General opinion makes it consist in some sort of equality". Also, in EE VII.1241a13-15: "All constitutions are a form of justice, for a constitution is a community, and everything common is established through justice". ${ }^{8}$

In Politics III.3, Aristotle argues that a polis cannot be identified by reference to its place or the race of its inhabitants, since it is only the constitution (nomos) of a polis which unites it:

If a city is a form of association, and if this form of association is an association of citizens in constitution, it would seem to follow inevitably that when the constitution undergoes a change in form, and becomes a different constitution, the city will likewise cease to be the same city. We say that a chorus which appears at one time as a comic and at another as a

\footnotetext{
${ }^{7}$ The notion of equality is also discussed at length in Nicomachean Ethics (V. 3) where Aristotle presents his theory on distributive justice. It should be pointed out, though, that Aristotle does not put forward the same account of justice in both the Nicomachean Ethics and the Politics, so one should be careful to first examine these two accounts separately and then try to understand Aristotle's conception of justice as a whole. I will not be discussing the $N E$ account of justice here, since my focus is on the Politics account. For a discussion of the $N E$ account of justice and the relevant bibliography, see Leontsini, E. The Appropriation of Aristotle in the LiberalCommunitarian Debate, op. cit., pp. 137-139.

${ }^{8}$ Aristotle's emphasis on equality is also stated in his discussion on community in various passages. A community is, according to Aristotle, a group which co-operates for the sake of some common good. This common good can vary from, for example, meals or property to eudaimonia: "There must be some one thing which is common to all the members and identical for them all, though their shares in it may be equal, or unequal. The thing itself may be various food, for instance, or a stretch of territory, or anything else of the kind" (1328a26-b1).
} 
tragic chorus is not the same-and this in spite of the fact that the members often remain the same. What is true of the chorus is also true of every kind of association, and of all other compounds generally. If the form of its composition is different, the compound becomes a different compound. A scale composed of the same notes will be a different scale depending on whether it is in the Dorian or the Phrygian mode. If this is the case, it is obvious that in determining the identity of the city we must look to the constitution. Whether the same group of people inhabits a city, or a total different group, we are free to call it the same city, or a different city. It is a different question whether it is right to pay debts or to repudiate them when a city changes its constitution into another form (Pol III.1276b l-10).

In particular, Aristotle discusses in Politics III.9-13 the relation of justice to constitutions, and to wealth. He approaches the classification of the constitutions from the point of view of justice. ${ }^{9}$ This account of justice that Aristotle puts forward in Politics III gives content to the account of justice by explaining what sorts of equality and inequality are relevant. This was not obvious from the account of justice presented in the Nicomachean Ethics. According to Aristotle, the principle of a constitution is its conception of justice. This is stated clearly in Politics III.1280a7-9, where he investigates the oligarchic and the democratic conceptions of justice, arguing that "all parties have a hold on a conception of justice; but they both fail to carry it far enough, and do not express the true conception of justice in the whole of its range." According to Aristotle, both oligarchy and democracy rest on a particular social class and have their own distinctive conception of justice concerning the way that offices and honours are distributed, which enables them to justify the predominance of the class they favour. ${ }^{10}$ Democrats think that the conception of justice is based on the principle of equality (equality in free birth), while oligarchs base justice on inequality (inequality in wealth). Aristotle's principle of political justice, conversely, is that political offices and honours should be distributed according to virtue. His own view is elaborated through the critique of the respective principles of the oligarchic and democratic constitutions.

Aristotle argues that justice is the political good: "Justice is concerned with people; and a just distribution is one in which there is proportion between the things distributed and those to whom they are distributed, a point which has already been made in the Ethics. There is general agreement about what constitutes equality in the thing, but disagreement about what constitutes it in people" ( $P$ ol III.1280a17-23). But, according to Aristotle, both sides, being misled by the fact that they are professing a sort of conception of justice, and professing it up to the point that they think they are professing one which is absolute and complete, fail to mention the 'real cardinal factor', as he calls it. The cardinal factor in this case is that the end of the city is the common promotion of a good quality of life and not only mere life.

As far as economic and social goods are concerned, Aristotle places the relative proportional equality, desert (kat' axian), as the distributive criterion for the person who lives "in the world as we know it" (Pol III.1280a33). This applies only to this kind of person, since in a society of exceptional people there is no place for anything

\footnotetext{
${ }^{9}$ Stalley, R. F. (1995) Aristotle. The Politics. Oxford: Oxford University Press, pp. 356-57.

${ }^{10}$ Stalley, R. F. Aristotle. The Politics, op. cit., p. 357.
} 
but absolute equality. It should be noted that Aristotle does not define the precise content of this proportional equality, but he simply attempts a formal analysis by leaving the criterion open. In the economic area, proportional equality is determined according to the contribution of each citizen ( $P o l$ III.1280a25-30). Furthermore, superiority of political rights is not allowed unless in the case of something that contributes to the excellence of performance (Pol III.1282b23-1283al). When laws are said to be 'right', the word must be taken to mean 'equally right', and this means 'right' in regard to the interest of the whole city and in regard to the common welfare of the citizens ( $P o l$ III.1283b40). In conclusion, seen in the context of the application of his principle of 'mean' and his theory on the best life, Aristotle argues that there should exist for everybody a minimum of social goods and that a maximum of goods should not be exceeded. ${ }^{11}$

\section{A Democratic Conception of Justice}

This democratic conception of justice that Aristotle presents sounds similar to the liberal definition of freedom. This may suggest that the state should be maximizing freedom, since democrats see freedom as a good. But the democratic conception of freedom should not be confused with the liberal one. If one takes this view to be the ancient conception of freedom that Aristotle is arguing about, then it is a democratic conception, but not a liberal one in the sense that part of its definition at least consists not in exercising freedom of choice but in having a share in rule. In fact, the conception of liberty at play here is that of 'ancient liberty' defined as 'democratic self-government'. ${ }^{2}$ Liberty is, for Aristotle, the end of democracy: "Nor should the end of each form of government be neglected, for people choose the things which have reference to the end. Now, the end of democracy is liberty, of oligarchy wealth, of aristocracy things relating to education and what the law prescribes, of tyranny self-protection" (Rhet I.1366a).

According to Aristotle, the democratic conception of liberty is defined by two features: (i) the interchange of ruling and being ruled, and (ii) living as you like. Freedom is, thus, the precondition of a democratic state:

The underlying principle of the democratic type of constitution is liberty. Indeed it is commonly held that liberty can only be enjoyed in this sort of constitution, for this, so they say, is the aim of every democracy. Liberty in one of its forms consists in the interchange of ruling and being ruled. The democratic conception of justice consists in arithmetical equality, rather than proportionate equality on the basis of desert. On this conception of justice

\footnotetext{
"It should be noted that the concept of 'mean' in the case of justice is different from that in the other virtues, because the mean in this case does not refer to the middle between two equally bad habits, but to a mean in relation to things.

${ }^{12}$ Ancient liberty is usually defined as 'self-mastery', but 'self-government' is a wider term including that of self-mastery, describing more precisely the nature of liberty for the ancients in the 'rule and being ruled' elements. See Leontsini, E. The Appropriation of Aristotle in the LiberalCommunitarian Debate, op. cit., pp. 220-222.
} 
the masses must necessarily be sovereign and the will of the majority must be ultimate and must be the expression of justice. The argument is that each citizen should be in a position of equality; and the result which follows in democracies is that the poor are more sovereign than the rich, for they are in a majority, and the will of the majority is sovereign. This then is one mark of liberty, which all democrats agree in making the defining feature of their sort of constitution. Another mark is 'living as you like'. Such a life, they argue, is the function of the free person, just as the function of slaves is not to live as they like. This is the second defining feature of democracy. It results in the view that ideally one should not be ruled by any one, or, at least, that one should [rule and] be ruled in turns. It contributes, in this way, to a general system of liberty based on equality (Pol VI. 2. 1317b2-17).

Aristotle's claim about the democrats, that they espouse freedom in the sense of doing what you wish, but nevertheless choose as 'second best' to rule and be ruled in turn, shows exactly that: participation in ruling leads to political liberty. If a person is participating in ruling, that means that he has a say in political decisions, she is able to put forward his views, she is at liberty to choose. Ruling, in turn, is a form of freedom since "it promotes my being able to do what I like". ${ }^{13}$ The basic assumption behind this idea is that negative liberty would never be secured unless political participation in government is guaranteed. Without being able to participate in government, negative liberty will almost always be arbitrary and subject to the good will of the occasional 'benevolent' sovereign or sovereign body.

The conflict between liberty and equality that Aristotle finds at the root of democracy is, of course, still unresolved. As he points out in Politics 1318a6-10, equality is for the poorer class to have no larger share of power than the rich, and not for the poorer class alone to be supreme but for all to govern equally. In this way, the worstoff would feel that the constitution possessed both equality and liberty. But, as he says in Politics VI.1318b39-41, unfortunately, liberty to do whatever one likes cannot guard against the evil that is in every person's character.

Aristotle argues in Politics V.1310a26-38 that democracy usually rests on a false conception of liberty. As he says, there are two features which are generally assumed to define democracy: the sovereignty of the majority and the liberty of individuals. Justice is assumed to consist in equality with regards to the will of the masses as sovereign; liberty is assumed to consist in "doing what one likes". But the result of this view is that in extreme democracies each individual lives as she likes and "she chances to desire for any end", as Euripides says. But, according to Aristotle, this is a false conception of liberty, since to live by the rule of the constitution should not be regarded as slavery, but rather as salvation. What is important in the city is for preservation and stability to be ensured, and this will not be achieved if the form of the constitution is based on such a conception of liberty.

For Aristotle, liberty is not a good to be pursued for its own sake; it is not prior to other values, such as justice, since the idea of liberty, on its political side, is ultimately based on the conception of justice. As Aristotle points out in Politics

\footnotetext{
${ }^{13}$ Sorabji, R. (1990) "Comments on J. Barnes," in Patzig, G. (ed.) Aristoteles Politik: Akten des XI. Symposium Aristotelicum. Göttingen, p. 266.
} 
VII.1324a5, where he examines the question of whether the happiness of the city is the same as that of the individual, or whether it is different:

Those who believe that the well-being of the individual consists in his wealth, will also believe that the city as a whole is happy when it is wealthy. Those, who rank the life of a tyrant higher than any other, will also rank the city which possesses the largest empire as being the happiest city. Anyone, who grades individuals by their goodness, will also regard the happiness of cities as proportionate to their goodness (Pol VII.1324a9-13).

The happiness of the city is the same as that of the individual only in the sense that in the same way that it is important for the individual to be wealthy, good, etc., it is also important for the city to be wealthy, good, etc.

From the above, we can draw the following conclusions regarding Aristotle's conception of liberty. Liberty in one of its forms consists in the interchange of ruling and being ruled (Pol VI.1317b2-3). This contributes to a general system of liberty based on equality (Pol VI.1317b15-17). But while the democrats adopt arithmetical equality, Aristotle supports proportionate equality. One form of liberty, as he says, is to govern and be governed in turn. This is the conception of liberty that Aristotle accepts; he denies the one form that the extreme democrat advocates, according to which liberty is to do whatever one wants. The idea of liberty, on its political side, is ultimately based on the conception of justice. But justice for Aristotle should consist in proportionate equality on the basis of desert and not in arithmetical equality as in the case of the democratic conception of justice (Pol VI.1317b2-11).

Although ideally one should not be ruled by any one, this is not possible since the state would dissolve into anarchy. In order to prevent this, a compromise should be made at the expense of liberty: one should live by the rule of the constitution. Living by the rule of the constitution ought, therefore, not to be regarded as slavery but as salvation ( $\mathrm{Pol}$ VI.1310a33-39). Aristotle argues that it is slavish to live for another with the crucial exception of a friend. If the ideal city rests on an extension of the best type of friendship, the virtuous person's relationship to the city is not slavish.

The greatest of all the means for ensuring stability of constitutions is the education of citizens in the spirit of their constitution. The citizens should be attuned, by the force of habit and the influence of teaching, to the right constitutional temper. It is true that to some extent Aristotle agrees that freedom is living as one wishes; but he denies that living as one wishes requires freedom from the constraints of law or moral education. Therefore, the democratic view is neither an individualist conception of freedom nor of justice. This is further enhanced by Aristotle's criticism of Lycophron's 'libertarian' view (Pol III.1280b10-11) and of Hippodamus's view (Pol II.1267b37). Aristotle is critical of both the oligarchic and the democratic conception of the state. Nevertheless, his arguments are not undemocratic as such; he is keener to demonstrate the dangers of democracy, than to criticize democracy as such.

Aristotle seems to envisage that a possible role of the state is to promote the good life but not to guarantee just claims. The state's job is not to arbitrate disputes. As he points out at $1280 \mathrm{~b} 6-12$, if the city does not devote itself to the end of encouraging 
goodness, a political association sinks into a mere alliance, which only differs in the contiguity of its members from other forms of alliance where the members live at a distance from one another. Thus, "the law becomes a mere covenant, or, in the phrase of the sophist Lycophron, 'a guarantor of just claims', but lacks the capacity to make the citizens good and just" ( $P o l$ III.1280b10-11).

In order to illustrate this point, Aristotle imagines a hypothetical case where two cities (Megara and Corinth) unite into one, being embraced by a single wall. This union, nevertheless, could not make a single city, since a polis is not an association of site (Pol III.1280b30) and "this sort of thing is the business of friendship, for the pursuit of a common social life is friendship":

It is clear, therefore, that a city is not an association for residence in a common site, or for the sake of preventing mutual injustice and easing exchange. These are indeed conditions which must be present before a city can exist; but the presence of all these conditions is not enough, in itself, to constitute a city. What constitutes a city is an association of households and clans in a good life, for the sake of attaining a perfect and self-sufficing existence. This, however, will not come about unless the members inhabit one and the self-same place and practice intermarriage. It was for this reason that the various institutions of a common social life-marriage-connections, kin-groups, religious gatherings, and social pastimes generally - arose in cities. This sort of thing is the business of friendship, for the pursuit of a common social life is friendship. Thus the purpose of a city is the good life, and these institutions are means to that end. A city is constituted by the association of families and villages in a perfect and self-sufficing existence; and such an existence, on our definition, consists in living a happy and truly valuable life (Pol III.1280b29-1281a1).

The pursuit of a common social life is, therefore, friendship, but, nevertheless, the purpose of a city is the good life and these institutions are means to an end. Therefore, Aristotle concludes at Politics III.1281a2-10 that it is for the sake of actions valuable in themselves, and not for the sake of social life, that political associations must be considered to exist. Those who contribute most to this association have a greater share in the city than those who are equal to them in free birth and descent, but unequal in civic excellence, or than those who surpass them in wealth but are surpassed by them in excellence. This, according to Aristotle, shows that the disputants about constitution profess only a partial conception of justice. It should be noted, nevertheless, that, although Aristotle's conception of the city as promoting virtue plays a part in this context, some of his arguments here are based on the idea that, in the world as we find it, where the ideal is not possible, we may have to choose the kind of constitution which is least prone to stasis. These are considerations which do not rest on a concept of desert, do not presuppose a thick theory of the good and could also be recognised by a modern. ${ }^{14}$

Aristotle gives great importance to criticising Lycophron's alternative view because his aim is to emphasise that-when discussing different conceptions of justice, and in particular equality and inequality relevant to the distribution of

\footnotetext{
${ }^{14} \mathrm{For}$ an interesting discussion on relevant criticisms of this Aristotelian argument, see Robinson, R. (ed.) (1995) Aristotle Politics, Books III and IV, with a supplementary essay by D. Keyt. Oxford: Clarendon Press, pp. 31-33.
} 
honours - it is important that we have first agreed on the end for which the city exists. The distribution of honours depends ultimately on the purpose for which the association exists. In that sense, Aristotle is able to discriminate between different conceptions of justice, and, also, to demonstrate that each conception of justice contains an element of truth. This is based on the assumption that we have agreed on the end for which the city exists. ${ }^{15}$ This criticism of Lycophron is similar to the argument against Hippodamus's theory made by Aristotle at Politics II.1267b37. Aristotle's first criticism of Hippodamus's theory concerns the division of the citizen body; all share in the constitution but not all of them bear arms and become, therefore, the slaves of the class in possession of arms.

\section{Justice, Moderation, and Political Friendship}

As we have seen in Sect. 1 of this chapter, justice, according to Aristotle, is important since its purpose is the common interest of the polis (to koine symferon). It is interesting that he also relates political friendship with the promotion of the common interest of the polis, regarding it as a special form of 'common advantage friendship' (to koine symferon), ${ }^{16}$ as it is obvious in various passages:

For people journey together with a view to some particular advantage, and to provide something that they need for the purposes of life; and it is for the sake of advantage that the political community too seems both to have come together originally and to endure, for this is what legislators aim at, and they call just that which is to the common advantage ( $N E$ VIII.I 160a11-14).

Aristotle points out that the political community is formed and survives for the sake of the common advantage that its members derive from it. In this sense, it is essential for such a community to aim at securing what is needed by its members to support their lives (NE 1160a11-23). All these different small communities, which exist within the larger political association, seem to be subordinate to this political community, because political community aims not at what is immediately useful, but at what is useful for the whole life:

All these communities, then, seem to be parts of the political community; and the particular kinds of friendship will correspond to the particular kinds of community (NE VIII.1160a28-30).

In $E E$ IX.1242a6-13, political friendship is also classified as "common advantage friendship':

Political friendship on the other hand is constituted in the fullest degree on the principle of utility, for it seems to be the individual's lack of self-sufficiency that makes these unions

${ }^{15}$ Stalley, R. F. (1995), op.cit., p. 358.

${ }^{16}$ For the definition of political friendship as 'common advantage friendship', see Leontsini, E. (2013) "The Motive of Society: Aristotle on Civic Friendship, Justice, and Concord," Res Publica, 19, 1 (2013), pp. 25-29. 
permanent-since they would have been formed in any case merely for the sake of society. Only civic friendship and the deviation from it are not merely friendships but also partnerships on a friendly footing ( $\hat{s}$ s philoi koinônousin); the others are on a basis of superiority. The justice that underlies a friendship of utility is in the highest degree just, because this is the civic principle of justice.

Aristotle maintained that 'philia is the motive of society' (Pol III.1280b38-39) and argued that friendship is even more important than justice since it generates concord in the city (NE VIII.1155b21-27).${ }^{17}$ Indeed, one of the most striking features of Aristotle's account is that he sees an important relation between justice and friendship. In his view, friendship is in some ways as important as justice - if not more - for the prosperity of the state. The city is a partnership for the sake of the good and-in the same sense that justice is the good in the sphere of politicsfriendship is also a good and holds the state together. Lawgivers, according to this argument, seem to care more for friendship than for justice, since friendship generates concord (homonoia)-i.e., unanimity of the citizens-which is similar to friendship. In that way, friendship can hold the state together-in the same sense that justice does - and can also expel faction. It is in this sense that, when people are friends, they have no need of justice, while when they are just, they need friendship as well, and the highest form of justice seems to be a matter of friendship. ${ }^{18}$

This view is expressed by Aristotle in both the Nicomachean and the Eudemian Ethics in two central passages, respectively. First, in NE VIII.1155a22-28 where he says that

Friendship seems also to hold states together, and lawgivers to care more for it than for justice; for concord seems to be something like friendship, and this they aim at most of all, and expel faction as their worst enemy; and when people are friends they have no need of justice, while when they are just they need friendship as well, and the truest form of justice is thought to be a friendly quality.

\section{Second, in $E E$ III.1234b25-31 where he expresses almost the same view:}

All say that justice and injustice are specially exhibited towards friends; the same person seems both good and a friend, and friendship seems a sort of moral habit; and if one wishes to make people not wrong one another, one should make them friends, for genuine friends do not act unjustly. But neither will people act unjustly if they are just; therefore justice and friendship are either the same or not far different.

Friendship and justice seem to be concerned with the same things and to be found in the same people:

For there seems to be some kind of justice in every community, and some kind of friendship as well. At any rate, people address as friends their shipmates and fellow soldiers, and similarly those who are members of other kinds of community or association with them. And the extent of their community is the extent of their friendship, since it is also the extent of

\footnotetext{
${ }^{17}$ For the importance of the relation between justice, friendship and concord in Aristotelian political philosophy, see Leontsini, E. "The Motive of Society: Aristotle on Civic Friendship, Justice, and Concord," op.cit., pp. 21-35.

${ }^{18}$ Leontsini, E. "The Motive of Society: Aristotle on Civic Friendship, Justice, and Concord," op.cit., p. 29.
} 
their justice. The proverb, 'What friends have, they have in common', is correct, since friendship is based on community. But while brothers and comrades have everything in common, what the others whom we have mentioned have in common is more limitedmore in some cases, less in others, since friendship too differs in degree ( $N E$ VIII.1159b25-1160a).

Again, similar examples are also offered by Aristotle in the Eudemian Ethics, where he says that:

Therefore to seek the proper way of associating with a friend is to seek for a particular kind of justice. In fact the whole of justice in general is in relation to a friend, for what is just is just for certain persons; and persons who are partners, and a friend is a partner, either in one's family or in one's life. For man is not only a political but also a house-holding animal, and does not, like the other animals, couple occasionally and with any chance female or male, but man is in a special way not a solitary but a gregarious animal, associating with the persons with whom he has a natural kinship; accordingly there would be partnership; and justice of a sort, even if there were no state (EE VII.1242a20-27).

Aristotle's view of political friendship is also closely connected with his advocacy of moderation in the mixed constitution in relation to justice, since equality of means produces the right kind of relationship among the citizens (which is a friendship among equals) and encourages, therefore, not only the right kind of political community but also a secure and stable political regime. ${ }^{19}$ Aristotle illustrates this in his discussion on the problems arising from a polis in which the distribution of wealth is unequal:

The result is a city, not of free persons, but only of slaves and masters: a state of envy on the one side and of contempt on the other. Nothing could be further removed from the spirit of friendship or of a political association. An association depends on friendship -after all, people will not even take a journey in common with their enemies. A city aims at being, as far as possible, composed of equals and peers, which is the condition of those in the middle, more than any group (Pol IV.1295b20-27).

According to Aristotle, the polity (politeia) is bound to have the best constitution, since it is composed of the elements which naturally go to make up a city. The middle classes enjoy a greater security themselves than any other class, since they do not, like the poor, desire the goods of others; nor do others desire their possessions, as the poor covet those of the rich, and since they neither plot against others, nor are plotted against themselves, they live free from danger. The best form of political association is, first, one where power is vested in the middle class, and, second, those cities where good government is attainable because there is a large middle class-large enough, if possible, to be stronger than both of the other classes, but at any rate large enough to be stronger than either of them singly; in that case, its addition to either will suffice to turn the scale, and will prevent either of the opposing extremes from becoming dominant. It is therefore the greatest of blessings for a city that its members should possess a moderate and adequate property. Where some have great possessions, and others have nothing at all, the result is either an extreme democracy or an unmixed oligarchy; or it may even be, as a result of the

${ }^{19}$ Hampton, J. (1997) Political Philosophy. New York: Westview Press, p. 154. 
excesses of both sides, a tyranny, since tyranny grows out of the most immature type of democracy, or out of oligarchy, but much less frequently out of constitutions of the middle order, or those which approximate them (Pol IV.1295b30-1296a12).

\section{The Relevance of Aristotelian Justice to Contemporary Political Theory}

Aristotle's account of 'polity' seems to be providing a good argument for distributive equality which is of contemporary relevance. The virtues of Aristotle's account can be seen by contrast with some standard contemporary accounts. According to Jean Hampton, "although Aristotle insists that there is such thing as natural slavery, he is even more insistent that the political relationship among people who are equals in their capacity to reason effectively ought to be constructed so that this equality is acknowledged". ${ }^{20}$ Indeed, Aristotle is attempting to characterize what constitutes a 'good' political system by relying on a consent-based theory of political authority: "a stable, effective and just political society is one in which the political authority, however it is structured, operates in a way that recognises the equality between the rulers and the ruled". ${ }^{21}$ Hampton thinks that Aristotle's theory is even a better alternative to 'welfare egalitarianism' and to Ronald Dworkin's 'resource egalitarianism', since Aristotle does not take for granted that equality is simply part of our conception of what a 'just' distribution is; in that connection, he offers an explanation and he believes that it is both possible and necessary to defend the link between equal distribution and justice by a moral argument. According to Aristotle, "distributive justice is a moral concept whose content we derive rather than discover, and we do so by understanding the way in which some distributions promote certain moral or social values better than others". ${ }^{22}$ That is, it serves a purpose rather than being an end in itself, which is, ultimately, mysterious and, thus, intellectually unsatisfying.

The question in contemporary political philosophy concerns the role of justice as an institution intended to fix the limits of human conduct. John Rawls's publication of $A$ Theory of Justice in 1971 agitated the then utilitarian dominated field of analytical political philosophy and gave a new turn to political discussion. At a time when some believed political philosophy to be dead, Rawls contributed to its revival

\footnotetext{
${ }^{20}$ Hampton, J. ibid, p. 153 .

${ }^{2 t}$ Hampton, J. ibid, pp. 32-33.

${ }^{22}$ Hampton, J. ibid, p. 158 . It should be noted here that recently there have been many valuable attempts to relate Aristotelian political theory to contemporary political egalitarian theory in general, such as Nussbaum, M. "Nature, Function, and Capability: Aristotle on Political Distribution," Oxford Studies in Ancient Philosophy, suppl. vol. (1988), pp. 145-184; "Aristotelian Social Democracy," in Douglass, R. B., Mara, G. \& Richardson, H. (eds.) (1990) Liberalism and the Good. London: Routledge, pp. 203-252; Sherman, N. (1997) Making a Necessity of Virtue. Aristotle and Kant on Virtue. Cambridge: Cambridge University Press, which I did not have space to discuss here.
} 
by abandoning utilitarianism and placing himself in the tradition of social contract theories and Kantian liberalism. Rawls brought forward questions of political obligation and the state, but, most important, he raised the issues of justice and the welfare state. What Rawls actually tried to do was to settle the old quarrel between liberty and equality, and to try to show that liberty could be made compatible with equality. Rawls famously begins his $A$ Theory of Justice with the almost axiomatic sentence that "Justice is the first virtue of social institutions, as truth is of systems of thought". ${ }^{23}$ Nevertheless, according to John Rawls, Aristotle could never be a liberal because he gives priority to a rational conception of the good rather than to justice. Rawls argues that justice is not prior for Aristotle, since in the definition of the polis we can find the good but not the concept of justice. ${ }^{24}$

A similar point, although of course in a very different direction from that of Rawls's, is made by the most notorious neo-Aristotelian communitarian critic of egalitarian liberalism, Alasdair MacIntyre, when he argues that Aristotle offers an instrumentalist conception of the polis: namely, that of covering the primary needs of the people (the living as survival), in the sense that the polis exists primarily for its members to survive. ${ }^{25}$ Aristotle is obviously far from arguing for equality in distribution. But it should be noted that, unlike modern writers on justice, Aristotle is more concerned with distribution of offices than with wealth. His arguments in Politics II suggest that he would object to wealth, partly because it is impracticable, but also because it is counter to his conception of virtue. His account of the ideal state suggests that people need a certain minimum of wealth, though this does not seem to be seen as a matter of justice. In addition, it should be pointed out that Aristotle is far from the idea that people have equal rights, or that they should be given equal opportunities. ${ }^{26}$

According to Aristotle, the just is equal as a mean of the inequalities of greed and inferiority, of profit and loss. The just involves persons and objects and is meaningful only in connection with four terms, and is a mean and an equal only in relation to these four terms. The relation of objects must be analogous to the relation of persons; if persons are equal, then they deserve equal shares; if they are not equal, then they will not have equal gain. So, Aristotle says, in the same way that everybody believes that the just is equal, everybody admits that also in distributive justice the just has to be distributed according to worth (kat' axian), from the principle of 'assignment by desert'. The dispute lies in the determination of the identity of desert as a criterion of distribution of the parties, because "all agree that justice in distributions must be based on desert of some sort, although they do not all mean the same sort of desert; democrats make the criterion freedom; those of oligarchic sympathies

\footnotetext{
${ }^{23}$ Rawls, J. (1971) A Theory of Justice. Oxford: Oxford University Press, p. 3.

${ }^{24}$ Rawls, J. A Theory of Justice, ibid., p. 360.

${ }^{25}$ Macintyre, A. (1985) After Virtue, 2nd ed. London: Duckworth.

${ }^{26}$ See on this Vlastos, G. "Justice and Equality," in Waldron, J. (ed.) (1984) Theories of Rights. Oxford: Oxford University Press, pp. 41-76 and von Leyden, W. (1985) Aristotle on Equality and Justice. His Political Argument. London: Macmillan, pp. 6-10.
} 
wealth; upholders of aristocracy make it virtue". ${ }^{27}$ In this way the criterion of distribution is 'proportion', the equality of logical relation, or geometrical equality - as Aristotle calls it - which is qualitative relation as opposed to the arithmetical or numeral equality that applies to corrective law and to friendship. In other domains of law other criteria apply. ${ }^{28}$

Nevertheless, Aristotle's treatment of Lycophron, that we have previously discussed, shows how far his conception is from that of the minimal state. It is also worth noticing that Aristotle does not have any account of procedural justice and, therefore, his accounts of rectificatory justice and of justice in exchange are based on fairness of outcome rather than fairness of procedure. Therefore, one could easily claim that Aristotle could not have much sympathy for Nozickean libertarianism. ${ }^{29}$ In addition, democratic justice seems to have much more in common with modern egalitarian liberal theories, since it emphasises freedom, equality of opportunity and equal political rights for citizens. Egalitarian Rawlsian liberal theory assumes (a) that there are many different conceptions of the good, and, (b) that none of these conceptions is preferable on a priori grounds. Therefore, the fundamental structure of a just society must be neutral between competing conceptions of the good. Aristotle accepts that there are in practice many competing conceptions of the good, but he does think that one is to be preferred a priori. He, therefore, thinks that an account of justice must be founded on that conception of the good. This is related to the question of whether the polis, or the state, is a natural entity or an artefact that comes into being naturally.

According to Aristotle, although it is natural for humans to form communities because it is in their nature to be with other people, the polis itself is not natural: it is an artefact that came to exist out of this natural need to be with other people. This is the way to reconcile the so-called inconsistency of Politics I, when Aristotle says that the person who first constructed the polis was the greatest of all benefactors. Unlike the extreme holist, Aristotle did not think that the polis is a substance; the polis is artificial and not a living organism. But what are we to make of Aristotle's suggestion that man is a political animal, and what bearing does this claim have on his conception of justice? Since it is in our nature to be social and to form associations, it is a necessary feature, and not a contingent one, that we live in a polis. Shared conceptions of the good are essential to the Aristotelian view, because otherwise one would not be able to form an association. It should be noted that both of the views that Aristotle examines (oligarchic and democratic) presuppose a conception of the good. The city itself should embody a conception of the good. This conception of the good could well be misguided, and hence a false one, as in the

\footnotetext{
${ }^{27} N E$ 1131a 28-31. This is related to MacIntyre's discussion of the notion of desert (MacIntyre, A. (1985) After Virtue. London: Duckworth, 2nd ed., pp. 244-255). In this case, people disagree "because they are bad judges in their own affairs" and also "because both the parties to the argument are speaking of a limited and partial justice, but imagine themselves to be speaking of absolute justice" (Politics, 1280a 20-22).

${ }^{28} N E 1131$ a 2, 1155a 27, 1157 b 36, 1158b 29-34, 1132b 21-33, 1134b 8-18, 1161a 20-1161 b 1.

${ }^{29}$ Nozick, R. (1974) Anarchy, State, and Utopia, Oxford: Blackwell.
} 
cases of democratic and oligarchic constitutions. If the polis is natural because it is essential for the good life, then one should know what the good life consists in and would have to be determined by the conception of the good life. The question is whether society is merely a means to achieve our own good, or an essential element in our own good. For Rawls, though, rules of justice are neutral between the different conceptions of the good life. By contrast for Aristotle, rules of justice are determined by the notion of the good life; the notion of desert is determined by our conceptions of the good, and offices and honours have to be distributed in accordance to virtue, or wealth, or equality-according to which conception of the good one holds. In Aristotle's view then, it would seem that, if the state is genuinely neutral between the different conceptions of the good, one could not really have justice, not even rectificatory justice. In conclusion, one should also point out that Aristotle presents kind of a consequentialist argument in defence of the existence of the state; he defends that state on the advantages of that state. There is no individualism explicit in his argument, but neither is the idea of a value-based state; the Aristotelian state is based on a notion of what is the best way to govern.

Acknowledgment I should like to thank Nick Zangwill for his insightful comments on an earlier draft of this chapter. 